\section{Zdzisław Żywica}

Uniwersytet Warmińsko-Mazurski, Olsztyn

zjzywica@poczta.onet.pl

ORCID: 0000-0003-3403-5108

DOI: http://dx.doi.org/10.12775/BPTh.2019.007

\section{Biblica}

et

Patristica

Thoruniensia

12 (2019) 2: 129-142

ISSN (print) 1689-5150

ISSN (online) 2450-7059

\title{
Sexuality/ Sexual Purity and Belonging to the 144,000 "Redeemed from the Earth and Purchased from among Mankind" in Light of Rev 14:1-5.
}

\author{
Płciowość i czystość seksualna \\ a przynależność do grona 144000 „wykupionych \\ z ziemi i spośród ludzi" w świetle Ap 14,1-5
}

\begin{abstract}
The author analyzes Rev 14:1-5 to answer the following questions: Are sex and sexual purity a necessary condition to belong to the group of 144,000 people gathered on "Mount Zion"? If so, who belongs to the group of "purchased from among mankind"? Are they men who are virgins endowed with the other two qualities, or male virgins and those who are not virgins but faithfully follow the Lamb and always tell the truth? If not, do women who are characterized by the same attributes as men belong to the group of the "redeemed"?
\end{abstract}

Streszczenie. Autor analizuje tekst Ap 14,1-5, by dać odpowiedź na następujące pytania: Czy płeć i czystość seksualna bezwzględnie warunkują przynależność do grona 144000 osób zgromadzonych na „górze Syjon”? Jeśli tak, to czy do grona „wykupionych" należą jedynie mężczyźni będący dziewicami ubogaconymi pozostałymi dwoma przymiotami, czy też mężczyźni dziewice wraz z tymi, którzy, choć nie są dziewicami, to jednak wiernie naśladują Baranka oraz zawsze mówią prawdę? Jeśli zaś nie, to czy w gronie „wykupionych” są również niewiasty charakteryzujące się tymi samymi atrybutami co mężczyźni?

Keywords: 144,000; Lamb; virgins; lie; firstfruits; blameless; follow; sexuality; purity.

Słowa kluczowe: 144 000; Baranek; dziewice; kłamstwo; pierwociny; bez skazy; naśladować; płciowość; czystość. 
On Mount Zion, in the presence of the Lamb, there are one hundred and forty-four thousand "redeemed from the earth" and "purchased from among mankind" "having his name and the name of his Father written on their foreheads." They are the only ones, who are able to learn the "new song" which is heard in heaven "before the throne and before the four living creatures and the elders." They are the only men who "did not defile themselves with women, for they remained virgins," "follow the Lamb wherever he goes," "were purchased from among mankind and offered as firstfruits to God and the Lamb and no lie was found in their mouths; they are blameless." The characteristics of the "purchased" defined in this way give rise to the following questions: Are the people mentioned in the passage of the same sex and do they constitute an ethically homogeneous group whose affiliation is conditioned by the first characteristic, which is a kind of conditio sine qua non for the remaining categories? If so, it should be understood that the group of 144,000 is made up solely of men who are virgins, namely, only those who "did not defile themselves with women, for they remained virgins" because thanks to this feature they were the only ones "redeemed from the earth" who were able to follow "the Lamb wherever he goes" and "a lie was not found in their mouths." All of them turned out to be "flawless" virgins. The assumption that this is a homogenous group made up entirely of men may also be supported by the masculine pronoun used in the text in the plural form (ou-toi) which precedes the attributes of the 144,000 "redeemed". However, does it imply that the author using the pronoun three times in the text suggests that there are three different categories of people who, thanks to their lifestyle, belong to the group of the 144,000 , creating a diverse unity of people united by the same "purchase" for the "firstfruits of God and the Lamb". Thus we would have in this group "those who are virgins" and those who "follow the Lamb wherever he goes", as well as those "in whose mouths no lie was found." They would form one community of 144,000 people, composed of three different "redeemed" groups and united by the absence of any "flaw" ("they are blameless").

As a result the question arises whether sex and sexual purity necessarily condition membership in the group of the 144,000 gathered on "Mount of Zion". If so, who belongs to the group of "purchased from among mankind"? Are they men who are virgins endowed with the other two qualities, or male virgins and those who are not virgins but faithfully follow the Lamb and always tell the truth? If not, do women who are characterized by the same attributes as men belong to the group of the "redeemed"? 
The search for the answers to these questions requires a detailed exegesis of verses $4-5$. The three demonstrative pronouns (ou-toi,) determine the order of text analysis in three stages. ${ }^{1}$

\section{1. "These are they who did not defile themselves with women,

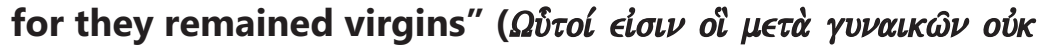

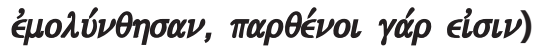

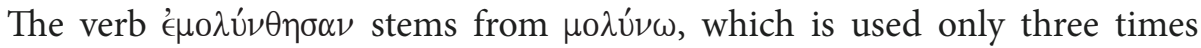
in the New Testament and denotes religious and moral defilement. ${ }^{2}$ In 1Cor 8:7

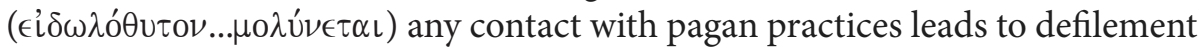
of conscience of people who have little faith. However, the expression $\mu 0 \lambda \dot{v} v \in \tau \alpha \iota$ refers here to the internal act of the person who chooses the weakness in the experience, therefore it is not a typical flaw resulting from the practice of idolatry. The other two cases are in the Book of Revelation. In 3:4, those "who have not

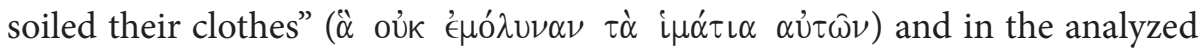
pericope; both illuminate each other. In 3:4, the context speaks more or less clearly about idolatry, but the expression itself is more general. It refers to some form of moral flaw, which could be deduced from the phrase "they have washed their robes" $(7: 14 ; 24: 14)$. However, it is too general and therefore cannot be reduced only to idolatry. In $14: 4$, the verb ' $\epsilon 0 \mathrm{O} \lambda \dot{v} \nu \theta \eta \sigma \alpha \nu$ ("have been defiled") in the passive voice, refers to the situation in which this defilement is forced on the subject from the outside, thus it is not a free choice and act of the person. These are the external hostile forces which try to defile them, and the entire

1 Rev 14:1-5 has a typical literary structure consisting of two parts.14:1-3 includes two parts expressed by a symbolic language: visual one (v. 1) and acoustic (vv. 2-3). The action takes place on earth, then is moved to heaven and again returns to earth. 14:4-5 has an applicative character. The author uses in this part a typical expression 'this is/ these are' where 'this/ these' have a symbolic character and refer to the preceding words whereas 'is/ are' refer to the current and given historical reality. In the Greek text this phenomenon is in-

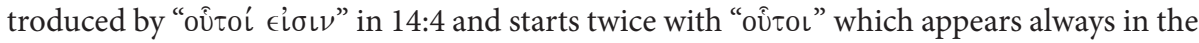
same verse. Thus, it indicates three categories of people who possess the features expressed in the symbolic image which directly precedes the description. Cf. U. Vanni, LAApocalisse. Una assemblea, p. 110; N. Hohnjec, Das Lamm, p. 115.

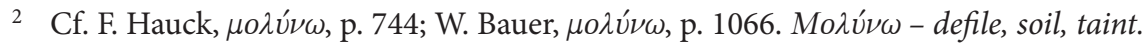

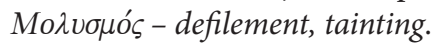


group of 144,000 did not take any initiative in this direction. Moreover, they even did not show such a thought, or any, more or less conscious, provocation. ${ }^{3}$

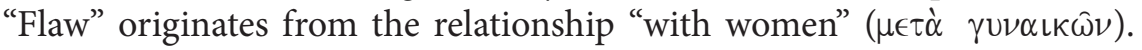
This expression indicates a sexual act as such, without specifying the circumstances of its occurrence. It may refer to both sexual intercourses in and out of marriage. Thus, any sexual act can lead to this type of "flaw". The term $\pi \alpha \rho \theta^{\prime} \operatorname{c} \nu \varsigma$ (virgin) in the Septuagint (LXX) is the semantic equivalent of the Hebrew term בְּתוּלָה and can denote generally: a maiden, a girl, ${ }^{5}$ a girl who has no sexual intercourse with a man, ${ }^{6}$ and in some cases clearly also virginity. ${ }^{7}$ It sometimes refers to the city or the lands and states to indicate that they are not conquered and subordinated. ${ }^{8}$ The people of Yahweh are also a virgin who did not defile herself and did not violate her purity through idolatry. ${ }^{9}$ In the New Testament, in some cases, the term is understood in accordance with its general meaning ${ }^{10}$ and refers directly to women. This may mean that they are maids, i.e. unmarried and free from sexual intercourse with a man. ${ }^{11}$ In the Pauline Letters it has an ascetic meaning, which refers to girls, and perhaps also to young men of a specific community in which they constantly reside together in order to realize in this way the idea of an ascetic Christian life. ${ }^{12}$ In our text, the term $\pi \alpha \rho \theta^{\prime} \in \mathcal{\nu}$ o may refer to both men and women, however, the first part of the sentence speaks of the relationships between men and women, which leads to the defilement of men: "these are they who did not defile themselves with women".

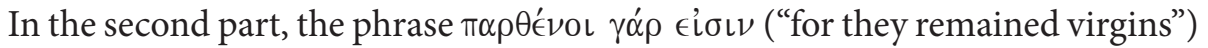

3 Ticonius, Alcazar, Bossuet, Karren, Bougatsos, among others, are in favor of idolatry (see more in: Ch. Brütsch, La clarté de l'Apocalypse); R.H. Charles, A Critical and Exegetical Commentary, pp. 1-11.421-424; M.E. Boismard, L’Apocalypse, pp. 507-541; A. Jankowski, Apokalipsa, p. 223; B. Maggini, L’Apocalisse, p. 137; A. Lancellotti, L'Apocalisse, p. 127; P. Prigent, L’Apocalisse, pp. 440-444; E. Schüssler Fiorenza, The Followers, pp. 132-134; E. Lohse, Objawienie, p. 105; P. Ostański, Objawienie, p. 249; H. Giese, Die Offenbarung, pp. 321-324.

4 Cf. P. Prigent, LApocalisse, p. 439, footnote. 7.

5 Cf. Dt 32:25; Ezk 9:6; Lm 1:4.

6 Cf. G. Delling, $\pi \alpha \rho \theta \epsilon ́ \nu 0 \varsigma$, p. 831.

7 Cf. Lev 21:13; Ex 44:22; Dt 22:23,28; Jdt 19:24; 21:11,12. J.M. Ford, The meaning of Virgin, pp. 293-299, maintains that many texts of Jewish and Christian literature using the

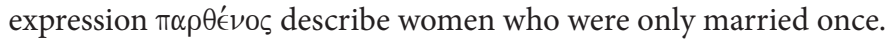

8 Cf. Is 47:1; 37:22; Am 5:2.

9 Cf. Jer 18:13-15.

10 Cf. Mt 25:1,7,11.

11 Cf. Acts 21:9.

12 Cf. G. Delling, $\pi \alpha \rho \theta \epsilon ́ \nu o \varsigma$, p. 835; J. MacArthur, Revelation, pp. 77-78. 
is usually applied to women. However, the author of the Book of Revelation extends the perspective on both men and women. It is about "redeemed from the earth" and "purchased from among mankind" $(14: 3,4)$, namely, the men and women who inhabit it, according to the biblical anthropology. ${ }^{13}$

The specific character of the whole sentence is determined by the particle $\gamma \alpha \dot{\alpha} \rho$ (because, for). In this way, it is confirmed that a certain category of people who have not been defiled with women are actually virgins. These two facts are not contradictory; on the contrary, they carry a certain stylistic tendency of the Book of Revelation. In addition, the fact of being virgins ( $\pi \alpha \rho \theta^{\prime} \in \nu$ ol $\gamma \alpha \dot{\alpha} \rho$ $\epsilon i \sigma\llcorner\nu$ ) introduced by $\gamma \alpha \dot{\alpha} \rho$ explains the first fact of being undefiled with women in natural concepts of physical virginity. ${ }^{14}$

The aforementioned analyzes determine that the most probable are metaphorical and natural interpretations. However, it should be remembered that the metaphorical interpretation is based on the model of idolatry as a betrayal of union which is known in the Old Testament. The people of Israel, devoting themselves to idolatry, broke the Covenant (a pact of love) which united them with God and made them His "spouse". The spouse had to remain faithful, but the attribute of virginity was never assigned to her and was not demanded of her. The analyzed text speaks of virginity and, in particular of virginity as an attribute of the group of 144,000, whereas the people of God in the Old Testament are shown, both in positive and negative light, always as a spouse. ${ }^{15}$ So if the metaphorical interpretation does not have a solid foundation which would fully authenticate it, then a realistic, natural interpretation becomes more likely. In this case, however, there is a huge difficulty to overcome: why virginity is combined with the expression "who did not defile themselves with women". The answer suggests a liturgical context in which the group listens to the word and acts in its apocalyptic experience. According to the concept, known in the Old Testament - especially in Ex 19:15 and 1Sm 21:5-6 - any sexual relationship, allowed or forbidden, was a contraindication to direct participation in religious practices. In these cases, it is a temporary contraindication (three days) which prevents people from direct or indirect contact with God.

This is how we could understand the expression "they did not defile themselves". The people to whom it refers, precisely in the symbolic image of the 144,000, have not done anything which prevents or hinders their contact with God. By saying "who did not defile themselves with women," the author of the

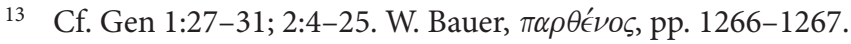

14 Cf. Rev 19:8.

15 N. Hohnjec (Das Lamm, p. 116) believes that both metaphorical and natural interpretations are possible.
} 
Book probably takes as a starting point the words of Ex 19:15 and 1Sm 21:5-6 and presents the categories of people who remain free of this contraindication and thus are constantly pure in a religious sense, which enables them to learn a "new song". The phrase in the first part of the sentence would have a symbolic value and would refer to permanent sacred purity indispensable for worship and participation in it. The second part of the sentence would explain that those who are in a state of permanent sanctity (sacred purity) possess the virtue of virginity understood in a natural sense. Virginity, therefore, makes it possible to understand and sing the "new song", creating a relation of the liturgical uniformity and unity among Christians and God. Such an interpretation has the advantage as it allows to explain adequately the text and to appreciate properly all its literary and philological elements, thus being the original contribution to the Old Testament theology of virginity. ${ }^{16}$ By understanding the text in a metaphorical sense and seeing in it a contraindication to engage in the liturgical "flaw", all dualistic and anti-feminist concepts are overcome. Natural virginity does not refer to all people of God, but only to a specific group of men and women "redeemed from the earth" and "purchased from among mankind" (14:3-4) who practice it for the benefit of other inhabitants of the earth. ${ }^{17}$

\section{2. "Those who follow the Lamb wherever he goes"

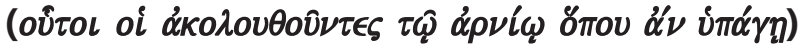

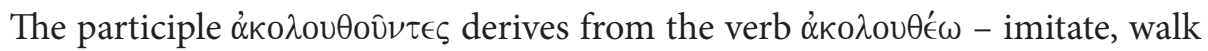
behind someone; be a disciple. ${ }^{18}$ In the Old Testament, it does not introduce a religious coloration but indicates the act of service performed by a servant to his master. ${ }^{19}$ The example of the two great prophets Elisha and Elijah and their relationship became a typical Pharisaic and later rabbinic term for the relationship between the disciple and the master: the Pharisee (rabbi) surpasses his disciple, and the latter follows him, accepting his teachings and style of life. ${ }^{20}$

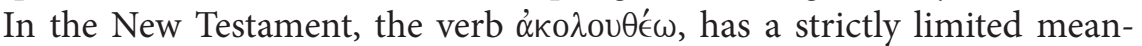
ing and expresses the following and imitating Jesus. It appears in four gospels and only once in the Book of Revelation, namely in the analyzed pericope. It is

\footnotetext{
16 Cf. Mt 19:12; 1 Cor 7:34.

17 Cf. U. Vanni, Questi seguono, pp. 181-183; Z. Żywica, Tożsamość, pp. 159-162;
}

S.J. Kistemaker, Exposition of the Book of Revelation, pp. 403-404.

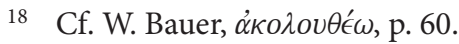

19 Cf.. Jdt 9:4,49; Jer 2:2; 1Kings 19:20.

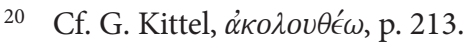


worth emphasizing that in the New Testament there is only its verbal form. Probably the form of noun which expresses imitation has been abandoned, because it stresses mostly the fact of following someone, not the very idea of imitation. It refers not only to the attitude of the twelve disciples towards Jesus (though this applies to most uses), ${ }^{21}$ but also to crowds ${ }^{22}$ and women. ${ }^{23}$ For

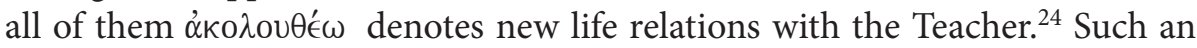
imitation is not an ordinary accompaniment to the other person, but places the

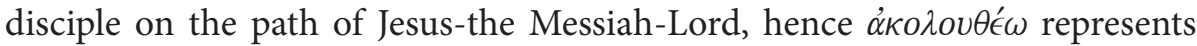
participation in the salvation offered by God in the person and work of Jesus. ${ }^{25}$ First, however, it marks participation in the destiny of Jesus, namely, the communion of life and suffering with the Messiah, the Son of Man, hence the presence under the cross of a disciple, crowds and women. ${ }^{26}$

While in the four gospels $\dot{\alpha} \kappa \circ \lambda$ ou $\theta^{\prime} \in \omega$ implies the choice of Jesus, which encompasses all their lives, in the analyzed text it does not refer either to a closed past or to an unknown future. However, it fully refers to the fullness of time with Christ - the Lamb of God killed and risen, who performs the work of salvation here and now. ${ }^{27}$ This is also confirmed by the fact that when the history of salvation for the Christ-the winner is fulfilled, He will be followed by soldiers who are in heaven, all dressed in fine linen, white and clean. ${ }^{28}$ The group of those who dedicate themselves to the full time of Christ the Lamb is able to learn the "new song" and expresses it with all the historical and saving dynamism. ${ }^{29}$ Not only men are present in it, but also women who followed Jesus from Galilee to the cross, placed Him in the tomb and were present at the morning of the resurrection. ${ }^{30}$ The phrase "wherever he goes" underlines the unrestricted availability of all these people to take and fully accept the situation

21 Cf. Mt 4:20,22; 8:23; Mk 1:18; 6:1; Lk 5:11; 22:39; Jn 1:37,38,40; Mt 8:10,19,22; 9:9; Mk 2:14; 10:32; Lk 5: 27,28; 9:57,59,61.

22 Cf. Mt 4:25; 8:1; 12:15; 14:13; 19:2; 20:29; Mk 3:7; 5:24; Lk 7:9; 9:11; 23:27; Jn 6:2; Mt 9:27; 20:34; Mk Lk 18:43.

23 Cf. Mt 27:55-56; Mk 15:40-41; Lk 23:48-49; Jn 19:25-27.

24 Cf. Mt 8:22; Lk 5:11; 9:61; Mk 10:28.

25 Cf. Lk 9:61; Mk 10:17,21; Jn 8:12; Mt 27:55-56; Mk 15:40-41; Lk 23:48-49; Jn 19:25-27.

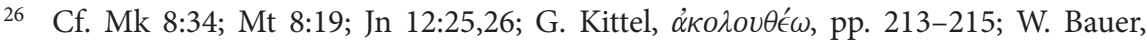

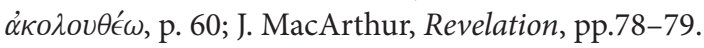

27 Cf. A. Jankowski, Apokalipsa, p. 223; H. Giese, Die Offenbarung, pp. 324-325.

28 Cf. Rev 19,14.

29 Cf. U. Vanni, Questi seguono, pp. 183-184; N. Hohnjec, Das Lamm, pp. 117-118.

30 Cf. Mt 27:55-56; Mk 15:40-41; Lk 23:48-49; Jn 19:25-27; Mt 27:61; 28:1-10; Mk 15:47; Lk 23:55-56; 24:1-10; Jn 20:1-18. 
of unexpected and demanding sacrifice, including the sacrifice of their own lives. ${ }^{31}$

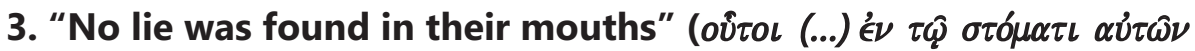

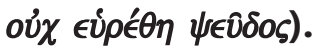

The phrase "no lie was found in their mouths" originates from the Old Testament, where in the juristic sense a lie ( $\left.\psi \in \hat{\in} \delta \delta \varsigma^{\prime}\right)$ is one of the most serious crimes, because the name Yahweh is used in it to make a false statement, and the Lord is the guardian of truth. The consequence can be only the curse of anyone who commits perjury. ${ }^{32}$ In the sapiential and moral sense, lies and liars are the subject of universal condemnation, because Yahweh is the guardian of truth and law. A typical argument of wisdom is: to lie is a nonsense. ${ }^{33}$ The relationship between ethics and the idea of God is not only external, on the contrary, the lie is directed against God Himself, therefore it has always been condemned especially by the prophets. ${ }^{34}$ In the religious sense, it appears in the context of infidelity towards God, idolatry and false prophecy. ${ }^{35}$

In the New Testament, the words 'to lie' and 'lies' are mainly used by Paul and John. ${ }^{36}$ Paul uses the verb 'to lie' according to the Old Testament and desacralizing scheme. ${ }^{37}$ The noun 'lie' is used to characterize the sinful behavior of all humanity, namely men and women, which consists in exchanging the truth of God for its denial, for untruth. ${ }^{38}$ Paul does not present any theory as to the origin of the lie, although in Rom 5:12 he states that sin entered the world through man. He also places it in an eschatological context when he states that the coming of the Antichrist will be accompanied by false signs. ${ }^{39} \mathrm{He}$ also ap-

31 Cf. Mt 16:24-27; Mk 8:34-38; Lk 9:23-26; U. Vanni, Questi seguono, pp. 183-184; Z. Żywica, Tożsamość, pp. 163-164; P. Ostański, Objawienie, p. 250; S.J. Kistemaker, Exposition of the Book of Revelation, p. 404.

32 Cf. Ex 20:16; Dt 5:20; Lev 5:21; Prov 6:16; 21:28; Zec 5:3.

33 Cf. Ps 4:3; 62:51; Prov 6:12-15; 17:7; 20:17; 26:23-28; Wis 10:14.

34 Cf. Hos 7:1,3,13; 10:13; Mic 6:12.

35 Cf. Am 2:4; Ps 40:5; Hos 7:13; Is 59:13; Jer 14:14;16:19; 23:17,32; Zec 13:2-6; Is 44:20; 57:4-6; Jer 3:23; 13:25. H. Concelmann, $\psi \epsilon \hat{\nu} \delta o \varsigma$, pp. 593-595; P. Prigent, L'Apocalisse, pp. 443; H. Giese, Die Offenbarung, p. 324.

36 In the Synoptic Gospels and the Acts of the Apostles the verb "to tell lies" appears only twice in Mt 5:11 and Acts 5:3.

37 Cf. Rom 9:1; 2 Cor 11:31; Gal 1:20.

38 Cf. Rom 1:25.

39 Cf. 2Thes $2: 9,11$. 
plies them in parenesis, especially in the catalogs of very severe sins committed by members of the Church, namely, Christian men and women. ${ }^{40}$ For John, the lie is the antithesis of truth $(\dot{\alpha} \lambda \dot{\eta} \theta \in L \alpha)$. It is not only a mistaken opinion for him, but the opposite of the truth, which means that it is disbelief, and the liar turns out to be a historical manifestation of the Antichrist. ${ }^{41}$

In the analyzed pericope, the phrase "no lie was found in their mouths" may refer to Zep 3:13 $3^{42}$ and Is 53:9. ${ }^{43}$ These texts indicate the honesty and rectitude of the Righteous and the Rest of Israel, namely the Israeli men and women. Literary contact with these texts, however, remains only contextual, because the author of the Book of Revelation does not wish to focus on a lie in a very general sense, understood as a wrong opinion. For him, the term 'lie' has a much deeper meaning. It is something that is done, not said. ${ }^{44}$ It can also refer to idolatry, to its specific and active practice. However, in Rev 22:15, the author mentions other practices which exclude from the gift of salvation, which clearly extends the moral context of lying: "Outside are the dogs, those who practice magic arts, the sexually immoral, the murderers, the idolaters and everyone who loves and practices falsehood." Thus, by expanding the text Is 53:99, he wants to say that no such immoral act, or any falsehood was committed by a group of 144,000 "redeemed". Thus, given John's understanding of the revelation of Christ as a call to "make the truth," it can be said that no lack and no other choice than the truth of Christ is visible in the attitude and speech of "the redeemed." 45 The existing state is fully compatible with the central evangelical truth, namely the unconditional and radical practice of a new life in Christ, which is chosen by the disciples, people from the crowd and women following Jesus. ${ }^{46}$ Such a practice of living corresponds fully to the profession of faith expressed in words, because the expression "in their mouths" indicates an oral proclamation. We can observe here a certain assessment made by God the Fa-

40 Cf. Col 3:9; Eph 4:25; 1Tim 1:9.

41 Cf. Jn 8:44,55; 1Jn 1:6; 2:4.21,27; 4:20. H. Conzelmann, yeu/doj, pp. 598-599; W. Bauer, yeu/doj, p. 779; P. Prigent, L’Apocalisse, pp. 443-444; Z. Żywica, Tożsamość, pp. 166167; J. MacArthur, Revelation, pp.79-80.

42 "They will do no wrong; they will tell no lies. A deceitful tongue will not be found in their mouths. They will eat and lie down and no one will make them afraid."

43 "He was assigned a grave with the wicked, and with the rich in his death, though he had done no violence, nor was any deceit in his mouth."

44 Cf. Rev 21:27; 22:15.

45 Cf. U. Vanni, Questi seguono, pp. 180-192; N. Hohnjec, Das Lamm, pp. 111-121; H. Ritt, Offenbarung, pp. 74-75; S.J. Kistemaker, Exposition of the Book of Revelation, p. 405.

46 Cf. Mt 4:25; 8:1; 12:15; 14:13; 19:2; 20:29; Mk 3:7; 5:24; Lk 7:9; 9:11; 23:27; Jn 6:2; Mt 9:27; 20:34; Mk Lk 18:43; Mt 27:55-56; Mk 15:40-41; Lk 23:48-49; Jn 19:25-27. 
ther and Christ the Lamb, because the phrase "no lie was found" is a theological and Christological passive which implies a test, assessment or judgment. ${ }^{47}$ Thus, the unity of this group with God and the Lamb, and not the sex of its members, leads us to the conclusion that it is God and the Lamb who make the judgment of their actual moral and spiritual state.

\section{4. "They were purchased from among mankind and offered as firstfruits to God and the Lamb; they are blameless"

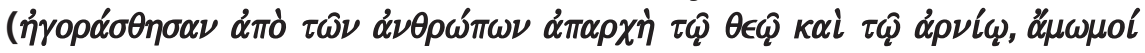 $\epsilon i \sigma \iota \nu)$}

The expression "firstfruits" ( $\alpha \pi \alpha \rho \chi \eta)$ in the Septuagint defines the sacrifice offered to God from the firstfruits of fields and pastures ${ }^{48}$ any sacrifice for the temple or priests, ${ }^{49}$ special acts, and especially religious (also pagan) works for the sanctuary ${ }^{50}$ or deities. ${ }^{51}$

St. Paul, using this term, refers to the Old Testament provisions concerning the offering to God in the form of the threshing floor and the dough presented as firstfruits. ${ }^{52}$ Developing the comparison "if the root is holy, so are the branches" and a metaphor "if the part of the dough offered as firstfruits is holy, then the whole batch is holy" he intends to show that God's election of Israel is still important, in which the firstfruits of Abraham's faith are a guarantee that the chosen people as a whole have a certain privileged share in God's salvific plan. In the same way, the household of Stephanas baptized by Paul is the firstfruits of Achaia, ${ }^{53}$ and Epenetus belongs to the firstfruits of Christ of Asia. ${ }^{54}$ In Rom 8:23, in a radical change of relationship between the giver and the receiver $\dot{\alpha} \pi \alpha \rho \chi \eta$ is the firstfruits offered to man by God, namely the gift of the Spirit, a deposit which will be fulfilled in the dignity of God's sonship. Thus this gift

\footnotetext{
47 Cf. U. Vanni, Questi seguono, pp. 185-186; J. Roloff, Die Offenbarung, p. 150; B. Maggini, L’Apocalisse, pp. 137-138; Z. Żywica, Tożsamość, p. 167; P. Ostański, Objawienie, p. 250.

48 Cf. Dt 18:4; 26:2,10; Num 5:9; 18:8-12,15; Ne 10:37; Ezk 45:13-16.

49 Cf. 2Chr 31:5.

50 Cf. Ex 25:2; 35:5; 36:6; Ezra 8:25.

51 Cf. Ezk 20:31. It is rarely used in a non-sacral meaning as a "portion" or "part". Cf. 1Kings 10:4; Dt 33:21; Ps 78[77]:51; 104:36.

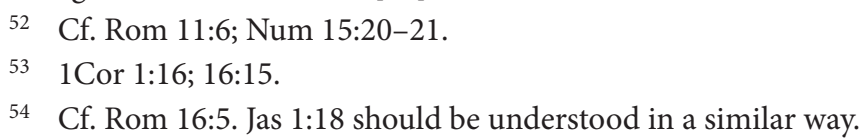


constitutes a definitive spiritual transformation of man. ${ }^{55}$ A similar idea appears in 1 Cor 15: 20-23, where Christ is called the firstfruits of those who have died and as the One who has been raised from the dead first. ${ }^{56}$

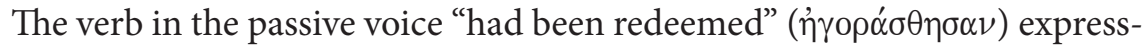
es the redemption already realized by God in Christ "from among mankind people" ( $\dot{\alpha} \pi \dot{c} \tau \hat{\omega} \nu \dot{\alpha} \nu \theta \rho \omega \dot{\omega} \pi \omega \nu)$, so those who were created by God in His image and likeness as men and women, and to whom He gave the earth ${ }^{57}$ so that they would subdue it. ${ }^{58}$ Syntagma "God and the Lamb" deepens the meaning of the "firstfruits" ( $\alpha \pi \alpha \rho \chi \eta)$ ). It indicates that it is the "firstfruits" which - referred to God - encompasses the activity of God in the history of all mankind, and referred to the Lamb - implements God's plan in the history of salvation - they concern His power, rule and control over the history. Those who imitate the Lamb create these firstfruits more in a functional sense as an active cooperation with Him than in a strictly cultic sense. Thus, this term cannot only refer to martyrdom. ${ }^{59}$ Instead, we should say that this is the "liturgy of history". 60

The term "blameless"/ "without fault" $(\alpha \mu \omega \mu \circ \varsigma)^{61}$ carries a liturgical meaning. In the Old Testament, it is used to indicate the absence of physical flaws, which made the animal worth sacrificing to God. ${ }^{62}$ In the New Testament, the image of a sacred offering free from physical defects is raised from the culticsacral to the purely religious and moral level. The absence of physical defects, which in the Old Testament was required for animals destined to sacrifice, finds its fulfillment in the integrity of Jesus the Redeemer who offers Himself voluntarily. ${ }^{63}$ In the Corpus Paulinum, the definition of Christians as "flawless" applies to their full life before God, namely, the constant worship of Him. ${ }^{64}$ In the Book of Revelation, the term refers to a fully integrated life in perfect unity

55 In Rom 8:23 $\dot{\alpha} \pi \alpha \rho \chi \eta$ denotes "temporal"

56 Cf. G. Delling, $\alpha \pi \alpha \rho \chi \dot{\eta}$, pp. 483-485; W. Bauer, $\alpha \pi \alpha \rho \chi \dot{\eta}$, p. 162; H. Giese, Die Offenbarung, p. 324; J. MacArthur, Revelation, p. 80.

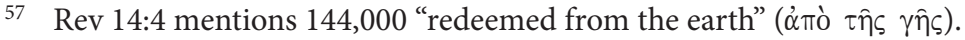

58 Cf. Gen 1:26-31.

59 Paul confirms it when he speaks of $\dot{\alpha} \pi \alpha \rho \chi \eta$ in a universal sense.

60 Cf. U. Vanni, Questi seguono, p. 185; A. Jankowski, Apokalipsa, p. 223. N. Hohnjec (Das Lamm, s. 119) opts for a religious -cultic sense, like P. Prigent, L’Apocalisse, pp. 442443.

61 Also: impeccable, innocent.

62 Cf. Ex 29:1; Lev 1:3; 4:3; 5:15; Ez 43:22, پپ $\mu \omega \mu$ o sometimes denotes religious and moral impeccability which is important if it is recognized by God. (2Kings 22:24; Prov 11:5; 20,7). F. Hauck, $\ddot{\alpha} \mu \omega \mu$ s, p. 836; W. Bauer, $\ddot{\alpha} \mu \omega \mu$ s, p. 93.

63 Cf. 1P 1:19; Heb 4:15; 7:26; 9:14. F. Hauck, پ̋ $\mu \omega \mu$ s, p. 836.

64 Cf. Eph 1:4; Phlm 2:15; Col 1:22. 
with God and Christ the Lamb in absolute truth, professed by the word and confirmed by action. This integrity has a liturgical dimension, because those who belong to the third category will be able to learn a "new song" in a liturgical celebration which finds its manifestation and embodiment in the liturgy of Christian life on earth among people. In this context, we should think of martyrs as the fullness of the sacrifice of their lives has been realized in the testimony of their death. ${ }^{65}$

\section{Variety in Unity}

The exegesis of the text allows us to state that the 144,000 people gathered on Mount Zion constitute one, strictly defined and distinguished from other people living on earth group which represents both men and women of different traits and attributes distinguishing individuals from each other. This varied mixture, on the one hand, reflects the diversity of their specific life conditions and, on the other hand, despite its internal diversity, allows all of these categories of people to learn the same "new song". The aforementioned characteristics can be applied separately to specific situations in which particular groups of people actually realize them in one aspect, and, at the same time, because of the similarity which arises from their values before God and the Lamb, it can become the reason for their easy combination. This expresses the multiplicity, diversity and colorfulness of life of Christians - both men and women - in the unity with God the Father and Christ the Lamb.

Thus, men and women can be found among the "redeemed 144,000", who, for Christ, have made a vow of chastity and practiced natural virginity, preserving the liturgical perfection, the lack of which would prevent them from imitating the Lamb whenever he goes. There are also those men and women who, endowed with the grace of the Spirit, cooperate with Christ in the salvation of other inhabitants of the earth, thus making His kingdom present. Finally, there are also those Christians, who have embraced the truth of Christ unconditionally and practice it in speech and conduct until the sacrifice of life, thus giving glory to God and the Lamb.

65 Cf. J. Cambier, L’Apocalypse, p. 125; R. Devine, The Virgin, pp. 1-5; Z. Żywica, Tożsamość, p. 168; J. MacArthur, Revelation, pp. 80-81; S.J. Kistemaker, Exposition of the Book of Revelation, p. 405. 


\section{Bibliography}

\section{Commentaries}

Beasly-Murray G.R., The Book of Revelation. New Century Bible Commentary, Grand Rapids 1981.

Cambier J., L'Apocalypse de Saint Jean lue aux Chrétiens, Paris 1955.

Charles R.H., A Critical and Exegetical Commentary on the Revelation of St. John, II, Edinburgh 1920.

Ellul J., Apocalypse: die Offenbarung des Johannes, Neukirchen 1981.

Giese H., Die Offenbarung des Johannes. Regensburger Neues Testament, Regensburg 1997.

Jankowski A., Apokalipsa św. Jana. Wstęp - Przekład - Komentarz, Poznań 1959.

Kistemaker S.J., Exposition of the Book of Revelation. New Testament Commentary, Grand Rapids 2001.

Lancellotti A., L'Apocalisse, Roma 1970.

Lohse E., Objawienie św. Jana, Warszawa 1985.

MacArthur J., Revelation 11-22, Chicago 2000.

Metzger B.M., A Textual Commentary on the Greek New Testament, London-New York 1971.

Prignet P., L’Apocalisse di S. Giovanni, trad. it. P. Brugnoli, Roma 1985.

Ostański P., Objawienie Jezusa Chrystusa. Praktyczny Komentarz do Apokalipsy, Ząbki 2005.

Ritt H., Offenbarung des Johannes. Die neue Echter Bibelkommentar zum Neuen Testament 21, Würzburg 1986.

Roloff J., Die Offenbarung des Johannes. Zürcher Bibelkommentare zum Neuen Testament 18, Zürich 1984.

Swete H.B., Commentary on Revelation, Grand Rapids 1977.

Vanni U., L'Apokalisse. Ermeneutica, esegesi, teologia. Edizione Dehoniane Bologna 17, Bologna 1991.

\section{Studies}

Bauer W., Griechisch-deutsches Wörterbuch zu den Schriften des Neuen Testament und übrigen urchristlichen Literatur, Berlin - New York $1988^{6}$.

Boismard M. E., "L’Apocalypse ou Les Apocalypses de St. Jean," Revue Biblique 56 (1949), pp. 507-541.

Brütsch Ch., La clarté de l'Apocalypse, Genève $1966^{5}$.

Collins A.Y., "Feminine Symbolism in the Book of Revelation," Interpetes 1 (1993), pp. 20-33.

Concelmann H., $\psi \epsilon \hat{v} \delta o \varsigma$, Theologisches Wörterbuch zum Neuen Testament, B. IX, G.Friedrich (hersg.), Stuttgart - Berlin - Köln 1990, pp. 590-599. 
Delling G., $\alpha \pi \alpha \rho \chi \dot{\eta}$, Theologisches Wörterbuch zum Neuen Testament, B. I, G. Kittel (hersg.), Stuttgart-Berlin-Köln 1990, pp. 483-488.

Delling G., $\pi \alpha \rho \theta \epsilon ́ \nu o \varsigma$, Theologisches Wörterbuch zum Neuen Testament, B. V, G. Kittel (hersg.), Stuttgart-Berlin-Köln 1990, pp. 824-835.

Devine R., The Virgin Followers of the Lamb, Scripture 16 (1964), pp. 1-5.

Ford J.M., "The Meaning of Virgin,” New Testament Study 12 (1965-66), pp. 293-299.

Hauck F., $\ddot{\alpha} \mu \omega \mu$ s, Theologisches Wörterbuch zum Neuen Testament, B. IV, G. Kittel (hersg.), Stuttgart-Berlin-Köln 1990, pp. 835-836.

Hauck F., $\mu \circ \lambda \dot{v} \nu \omega$, Theologisches Wörterbuch zum Neuen Testament, B. IV, G. Kittel (hersg.), Stuttgart-Berlin-Köln 1990, pp. 744-750.

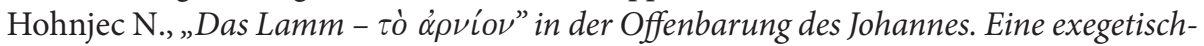
theologische Untersuchung, Roma 1980.

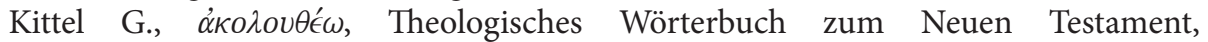
B. I, G. Kittel (hersg.), Stuttgart-Berlin-Köln 1990, pp. 213-216.

Lindijer C.H., Die Jungfrauen in der Offenbarung des Johannes 14,4, in: Fs. J.N. Sevenster, Brill - Leiden 1970, pp. 124-142.

Maggini B., L’Apocalisse per una lettura profetica del tempo presente, Assisi $1988^{3}$.

Power E., "A Pretended Interpolation in the Apocalypse (Apoc 14,4s)," Biblica 4 (1953), pp. 100-115.

Schüssler Fiorenza E., “The Followers of the Lamb: Visionary Rhetoric and Social-Politic Situation," Semeia 36 (1986), pp. 123-146.

Tambyah T. I., "Virgins in Apoc 14, 4," Expository Time 32 (1920-21), p. 139.

Vanni U., L'Apocalisse: ermeneutica, esegesi, teologia, Bologna 1991.

Vanni U., "Questi seguono l'agnello dovunque vada (Ap 14, 4)," Parola, Spirito e Vita 2 (1980), pp. 171-192.

Vanni U., L’Apocalisse: una assemblea liturgica interpreta la storia, Brescia $1995^{8}$.

Vanni U., La struttura letteraria dell'Apocalisse, Roma 1971.

Weichts W., "Die dem Lamme folgen. Eine Untersuchung der Auslegung von Offb 14,1-5 in den letzen 80 Jahren," Theologische Rundschau 75 (1979, pp. 372-375.

Żywica Z., "Tożsamość stu czterdziestu czterech tysięcy wykupionych z ziemi. Studium egzegetyczne Ap 14,1-5," Forum Teologiczne I, pp. 145-170. 